\title{
Publicidade nos Cadernos de Saúde Pública
}

A presença de publicidade em revistas científicas vem de longa data. No presente, é visível em periódicos das mais diversas áreas do conhecimento. A recorrência dos anúncios não significa, contudo, que prevaleça uma relação necessariamente harmoniosa entre editores e anunciantes. Pelo contrário, ela pode ser bastante tempestuosa, uma vez que os princípios que norteiam as atividades acadêmico-científicas e as comerciais não raro colidem. Desnecessário enfatizar que é sumamente importante que os editores estejam atentos à possível influência da indústria (e, por conseguinte, de interesses comerciais) nas etapas do processo de produção e divulgação do conhecimento científico.

$\mathrm{Na}$ área biomédica, o financiamento por parte da indústria de atividades de pesquisa é prática disseminada. É difícil delinear com clareza até que ponto "financiamento" pode implicar "direcionamento", mas, sem dúvida, tal associação faz-se presente. Muitos leitores hão de se lembrar da recente celeuma relacionada às pesquisas financiadas pela indústria de tabaco, que isentavam a nicotina de qualquer papel na indução à dependência química.

Como observou R. Horton, editor de The Lancet1, mais que financiamento, preocupam as possíveis influências exercidas pelos interesses comerciais no delineamento do desenho do estudo, bem como nas etapas de análise e interpretação dos dados. Nesse sentido, o Grupo de Vancouver determina que os autores não devem firmar contratos que venham interferir em sua tomada de decisão acerca de o que e como publicar2. Tais questões giram em torno de dois princípios fundamentais à boa prática científica: liberdade e independência. Esses princípios não se materializam no vácuo; demandam um enorme esforço para que se concretizem como dinâmicas cotidianas. Os editores de revistas científicas não podem desviar a atenção desses princípios; ao mesmo tempo, devem se ocupar da tarefa de asseverar a contínua qualidade científica das publicações sob sua responsabilidade, para não mencionar a viabilidade econômica.

O aumento no número de artigos submetidos anual mente a Cadernos de Saúde Pública (CSP), simultaneamente à rápida expansão do sistema de distribuição da revista, implicou em acentuada elevação de custos. Para fazer face a essa demanda, foi criado um encarte publicitário que tem como objetivo recursos suplementares. Outras alternativas largamente utilizadas no meio editorial-científico, como a elevação do preço da assinatura anual e/ ou a cobrança para a publicação de artigos, pareceram-nos incompatíveis com o perfil de nosso público. A veiculação de publicidade paga, desde que pautada em princípios éticos de ampla circulação no meio editorial internacional2,3, configurou-se como uma alternativa factível a curto prazo, em associação, obviamente, com outras fontes de suplementação orçamentária, que incluem instituições e agências governamentais e não governamentais.

A política dos CSP para publicidade considerará a possibilidade de publicação de anúncios de produtos diversos relacionados ao exercício das diversas profissões de saúde, incluindo pesquisa médica e biológica; lançamentos editoriais; serviços diversos (bancos, seguradoras, informática, etc.); cursos etc. Naturalmente, não serão aceitos anúncios de produtos que, comprovadamente, causem danos à saúde (exemplo: tabaco). Visando salvaguardar o conteúdo editorial-científico, os anunciantes não terão acesso prévio ao conteúdo dos fascículos. Os anúncios serão sempre publicados em encartes especiais separados, inseridos no início e/ ou final da revista; nunca em meio aos artigos. Na seção "Cartas", críticas e considerações acerca de anúncios poderão ser publicadas, desde que de acordo com as normas editoriais de CSP.

Carlos E. A. Coimbra Jr. \& Luis David Castiel

Editores

Horton, R., 1997. Lancet, 349:1411-1412.

International Committee of Medical Journal Editors, 1997. Ann Intern Med, 126:36-47

3 International Committee of Medical Journal Editors, 1995. Can Med Assoc J, 152:1647-1650. 


\section{Advertising in Cadernos de Saúde Pública}

Advertising has been used in scientific journals for a long time. At present, one finds advertisements in periodicals from a wide range of fields. However, the fact that certain advertisements appear in successive issues of the same journal does not necessarily reflect a harmonious relationship between the editors and advertisers. On the contrary, it is not rare for the underlying principles in academic/scientific and commercial activities to clash. One need not emphasize how crucial it is for editors to be alert to the possible influences of industry (and thus commercial interests) in the various stages of producing and publishing scientific information.

Research funding by industry is a widespread practice in the biomedical fields. It is difficult to clearly demarcate to what extent "funding" involves "orientation", al though such an association is no doubt present. Readers are sure to remember the recent outcry over research funded by the tobacco industry, exempting nicotine from any role in inducing chemical dependence on smoking.

As observed by R. Horton, Editor of The Lancet1, more than the funding itself, cause for real concern is the possible influence exerted by commercial interests in defining the actual research design, as well as the data analysis and interpretation stages. In this sense, according to the "Vancouver Group", authors should not sign contracts that interfere in their decision-making as to what and how to publish2. Such topics revolve around two basic principles in scientific practice: freedom and independence. Such principles do not materialize in a void; great effort is needed to make them a reality in daily dynamics. Editors of scientific journals must not divert their attention from these principles; at the same time, they must focus on the task of guaranteeing the on-going scientific quality of the publications under their responsibility, not to mention their economic viability.

The increasing number of articles submitted yearly to Cadernos de Saúde Pública (CSP), along with the rapid expansion of the journal's distribution system, have led to a sharp increase in costs. To deal with this demand, an advertising insert has been created in order to raise additional funds. In our opinion, other alternatives widely used in the scientific publishing community, like increasing the annual subscription price or charging for publishing articles, are incompatible with our reader and author profiles. Carrying paid advertising, with the condition that it be based on ethical principles widely accepted by the international publishing community2,3, appeared to us to be the most feasible short-term alternative, evidently in combination with other ways to supplement our publishing budget, such as funding from governmental and nongovernmental institutions and agencies.

The advertising policy at CSP includes the possibility of publishing ads for various products related to the different health professions, including medical and biological research, book and periodical releases, services (banking, insurance, information technology, etc.), courses, etc. Obviously, advertisements for products that are proven to be harmful to health (tobacco, for example) will not be accepted. In order to safeguard the journal's editorial and scientific content, advertisers will not have prior access to the issues. All advertisements will be published in separate special inserts located at the beginning and/or end of the journal, but never in the middle of the articles. Through the "Letters" section, criticism and comments pertaining to the advertisements may be published, so long as they comply with the editorial norms and standards of CSP.

\section{Carlos E. A. Coimbra Jr. \& Luis David Castiel}

Editors

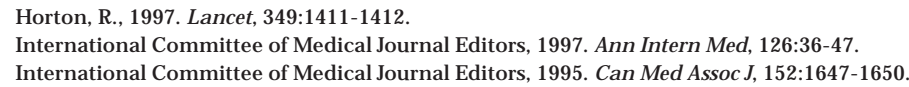

